
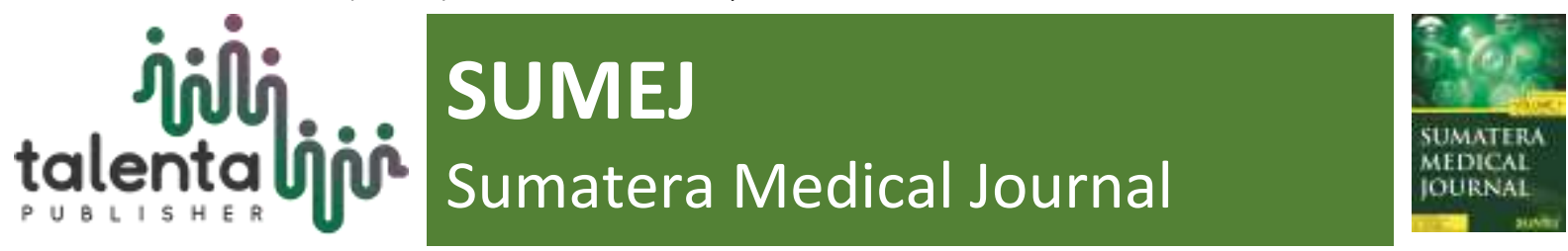

\title{
Effectiveness of Vitamin A in Albendazole Against Reinfection of Ascaris Lumbricoides
}

\author{
Richo Wijaya ${ }^{*}$, Munar Lubis $^{2}$, Selfi Nafianti ${ }^{3}$, Inke Nadia Lubis ${ }^{4}$ \\ 1,2,3,4 Department of Child Health, Faculty of Medicine Universitas Sumatera Utara, Indonesia
}

\begin{abstract}
WHO recommends the supplementation of 200,000 IU vitamin A into $400 \mathrm{mg}$ albendazole to cut down its reinfection. A Randomized Controlled Trial was conducted in SD N 384 Sikapas, North Sumatera from April - June 2016. Inclusion criteria were children with ascariasis. Sample divided into intervention and control group. Kato-Katz was used to identify egg worms and faecal egg count intensity (FECs). P value $<0.05$ was consider significant. After three months follow up, there were 51 and 56 samples in intervention and control group with average age 9.6 years (SD 1.99) and 9.7 years (SD 2.20). Prevalence of ascariasis was $75.5 \%$. There was no significant difference in Ascaris lumbricoides reinfection but instead of in FECs intensity. The NNT was 22.31. The addition of vitamin A in albendazole was not suggested according to this study.
\end{abstract}

Keyword: Vitamin A, Ascaris Lumbricoides, Albendazole, Effectiveness

\begin{abstract}
Abstrak. WHO merekomendasikan suplementasi 200.000 IU vitamin A ke dalam $400 \mathrm{mg}$ albendazole untuk mengurangi infeksinya. Uji coba Randomized Controlled dilakukan di SD $N 384$ Sikapas, Sumatera Utara dari April - Juni 2016. Kriteria inklusi adalah anak-anak dengan ascariasis. Sampel dibagi menjadi kelompok intervensi dan kontrol. Kato-Katz digunakan untuk mengidentifikasi cacing telur dan intensitas menghitung telur faecal (FECs). Nilai $P<0,05$ dianggap signifikan. Setelah tiga bulan tindak lanjut, ada 51 dan 56 sampel dalam kelompok intervensi dan kontrol dengan rata-rata usia 9,6 tahun (SD 1,99) dan 9,7 tahun (SD 2,20). Prevalensi ascariasis adalah 75,5\%. Tidak ada perbedaan yang signifikan dalam reinfeksi Ascaris lumbricoides tetapi bukan pada intensitas FEC. NNT adalah 22,31. Penambahan vitamin A dalam albendazole tidak disarankan menurut penelitian ini.
\end{abstract}

Kata Kunci: Vitamin A, Ascaris Lumbricoides, Albendazole, Efektivitas

Received 4 January 2019 | Revised 16 January 2019| Accepted 31 January 2019

${ }^{*}$ Corresponding author at: Faculty of Medicine, Universitas Sumatera Utara, Indonesia 


\section{Introduction}

The incidence of helminthiasis in development coun-try was still high. The main cause of intestinal parasitic infections was Ascaris lumbricoides [1-3]. Ascariasis spread all over the world and approximately infected more than 1.000 people [4]. In Indonesia, a cross-sectional study in Bali has reported that incidence of ascariasis reached $73,7 \%$ from 2.934 samples [1]. In Karo region, Suka Village Noth Sumatra, an incidence of ascariasis in primary school was 89,7\%. [5]. In Medan-North Sumatra, infection of Ascaris lumbricoides in primary school was 64,5\% [6]. That evidence showed that high endemicity of ascariasis in North Sumatra.

Ascariasis could impair children growth and development. Short-term efforts in eradicating ascariasis, anti-helminth drug, albendazole, could be used. According to a study in North Sumatra, giving $400 \mathrm{mg}$ of albendazole was still effective in reducing re-infection of Ascaris lumbricoides [7]. Seventy-five percent countries with vitamin A deficiency were endemic of helminthiasis. The observational and clini-cal trial in 1920 and 1930 reported that vitamin A role as anti-infection, immunomodulator, by maintaining the integrity of membrane mucous, increased immunoglobulin A (IgA) and humoral immunity [8]. World Health Organization (WHO) recommended "preventive chemotherapy" against helminthiasis by adding 50.000-200.000 IU of vitamin A. Its expected result after deworming accompanied by giving vitamin A could decrease prevalence and intensi-ty of helminthiasis [9]. A study in Canada reported that giving vitamin A in albendazole decreased ascariasis $[10,11]$. The interaction between albendazole and vitamin A was still unclear.

\section{Methodology}

The study took place in Primary School SD 384 Sikapas, Singkuang village, Mandailing Natal, North Sumatera from April 2016 until June 2016. All primary school children from grade I-VI were examined their stool to find eggs worm, Ascaris lumbricoides. To collect stool, every child was given a stool pot at school and returned the next day. The stool was examined under the microscope by using Kato-Katz method. Egg worm intensity was divided into mild (1-4.999 eggs), moderate (5.000-49.999) and severe ( $\geq 50.000)$. Worm infected children besides Ascaris lumbricoides or mix infection were excluded. Samples were divided into two groups, intervention (400 mg albendazole plus $200.000 \mathrm{IU}$ vitamin A) and control (400 mg albendazole and placebo), and excluded samples were treated with albendazole $400 \mathrm{mg}$. Treatments were given by teacher and observer. The stool was re-examined a week after treatment. Uninfected samples were followed up for three months and re-examined the stool to look for re-infection. Two hundred and eighty students were enrolled in this study, but only 200 students were eligible. Inform consent was known by children's parents. Data were analyzed with Statistical Package for Social Sciences for Windows (SPSS), 19 version, 2010 with 95\% of the confidence interval, p-value < 0,05 was considered as significant. Randomisation was used Microsoft Excel Randomisation. Chi-square test was performed to define re-infection and eggs worm intensity. Wilcoxon test was used to 
evaluate discrepancy eggs worm intensity before and after treatment between intervention and control group. The ethical research was confirmed.

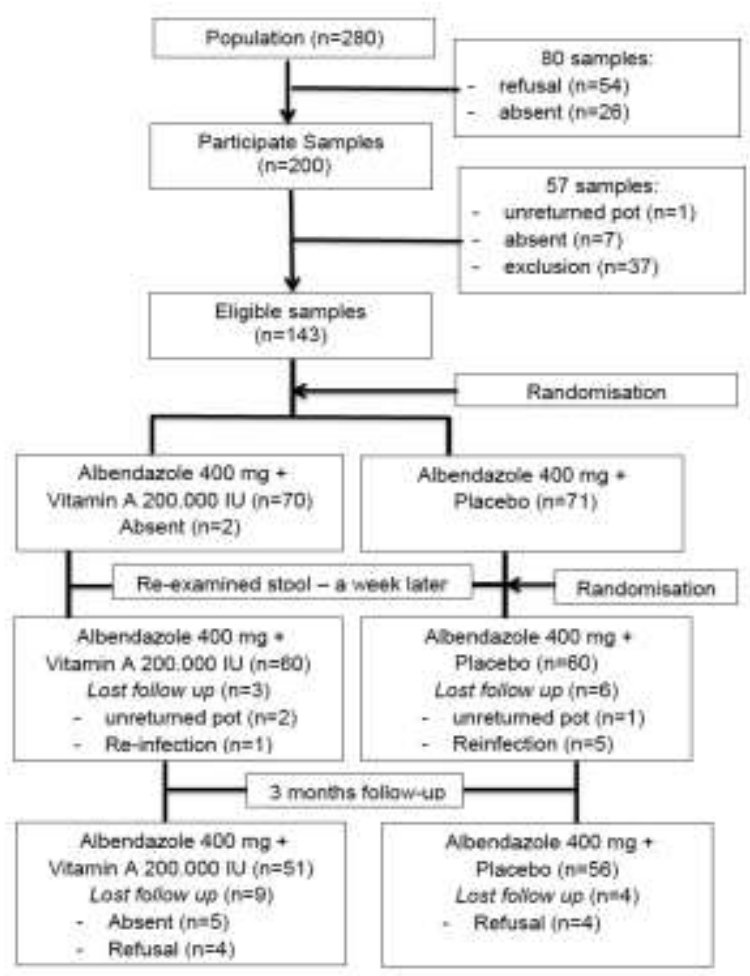

Figure 1. Consort Diagram

\section{Result}

Of the 280 primary school children, SD N 384 Sikapas, Singkuang village, Mandailing Natal, North Sumatra, were enrolled. Only 200 children intend to participate in this research, but 143 children were suitable with inclusion criteria. From randomization, 70 and 71 children were into intervention and control group, respectively. There were 60 samples in each group with negative eggs worm results after a week treatment and followed up for three months with the remaining sample was 51 and 56 samples in intervention and control group (Figure 1).

Study population characteristic showed that in both groups, boy was more than the girl. Mean age sample for each group, intervention and control group, was 9,6 (SD 1,99) years old and 9,7 (SD $2,20)$ years old. There was no significant difference in mean height, mean body weight and the number of siblings in each group. (Table 1). 
Table 1. Study Population Characteristic

\begin{tabular}{lcc}
\hline Characteristic & $\begin{array}{c}\text { Intervention } \\
(\mathrm{n}=51)\end{array}$ & $\begin{array}{c}\text { Control } \\
(\mathrm{n}=56)\end{array}$ \\
\hline $\begin{array}{l}\text { Sex, } \mathrm{n}(\%) \\
\quad \text { Boy } \\
\text { Girl }\end{array}$ & $26(9.29)$ & $\begin{array}{c}29(10.36) \\
27(9.64)\end{array}$ \\
& $25(8.93)$ & \\
Age, years (SD) & $9.6(1.99)$ & $9.7(2.20)$ \\
$\begin{array}{l}\text { Mean hegiht, cms } \\
\text { (SD) }\end{array}$ & $128.2(11.47)$ & $126.7(10.48)$ \\
$\begin{array}{l}\text { Mean body } \\
\text { weight, kgs (SD) }\end{array}$ & $26.7(6.93)$ & $25.6(7.10)$ \\
$\begin{array}{l}\text { Mean of siblings, } \\
\text { mean (SD) }\end{array}$ & $3.7(2.26)$ & $3.6(1.67)$ \\
\hline
\end{tabular}

Overall, prevalence Ascaris lumbricoides infection was $75.5 \%$ followed by $23.8 \%$ mix infection (Ascaris lumbricoides and Trichiuris trichiura) and 0.7\% Oxyuris vermicularis. (Table 2)

Table 2. Prevalence of Helminthiasis

\begin{tabular}{lr}
\hline Type of Worm & Percentage \\
\hline Ascaris lumbricoides & $75.5 \%$ \\
Trichiuris trichiura + & $23.8 \%$ \\
Ascaris lumbricoides & \\
Oxyuris vermicularis & $0.7 \%$ \\
Type of Worm & Percentage \\
Ascaris lumbricoides & $75.5 \%$ \\
Trichiuris trichiura + & $23.8 \%$ \\
Ascaris lumbricoides & \\
Oxyuris vermicularis & $0.7 \%$ \\
Type of Worm & Percentage \\
Ascaris lumbricoides & $75.5 \%$ \\
\hline
\end{tabular}

This study reported that after three months followed up, we found $43 \%$ (46/51 samples) and $44.9 \%$ (48/56) samples in the reinfected state, the remaining was $4.7 \%$ and $7.5 \%$ samples in the uninfected state, respectively for intervention and control group. The relative risk ratio for both groups was 0.786 . Findings at the three months assessment showed that there was no significant difference in the reinfection rates in both groups $(\mathrm{p}>0.05)$. (Table3). 
Table 3. Association of Ascaris lumbricoides Reinfection

\begin{tabular}{lcccccc}
\hline Reinfection & $\begin{array}{c}\text { Intervention } \\
\mathrm{n}(\%)\end{array}$ & $\begin{array}{c}\text { Control } \\
\mathrm{n}(\%)\end{array}$ & $\mathrm{X}^{2}$ & $\mathrm{RR}$ & \multicolumn{2}{c}{$\mathrm{P}^{*}$} \\
\hline Yes & $46(43.0)$ & $48(44.9)$ & 0.502 & 0.786 & $\begin{array}{c}0.47 \\
8\end{array}$ \\
& & & & & \\
No & $5(4.7)$ & $8(7.5)$ & & & \\
& & & & & \\
\hline
\end{tabular}

* Chi-square test

Effects of vitamin A supplementation on Ascaris lumbricoides reinfection intensities. The effect of the interventions on the intensities of A. lumbricoides reinfection after three months are shown in Table-3. As the result of deworming, the intensities of A. lumbricoides infections in both groups after three months of receiving interventions were significantly different from control (Wilcoxon test; $p<0.05$ ). The percentage of the egg worm intensity was $47.7 \%$ versus $52.3 \%$ and $43.0 \%$ versus $44.9 \%$, respectively for before and after deworming in intervention and control group. There was only $4.7 \%$ versus $7.5 \%$ negative egg worm in intervention and control group after deworming with the p-value $<0.05$ (Table 4).

Table 4. Intensity Difference of Egg Worm

\begin{tabular}{|c|c|c|c|c|}
\hline Egg Worm Intensity & Intervention $\mathrm{n}(\%)$ & $\begin{array}{c}\text { Control } \\
\mathrm{n}(\%)\end{array}$ & $\mathrm{X}^{2}$ & $\mathrm{P}^{*}$ \\
\hline $\begin{array}{l}\text { Before deworming, n (\%) } \\
\text { Negative } \\
\text { Mild }\end{array}$ & $\begin{array}{c}0(0) \\
51(47.7)\end{array}$ & $\begin{array}{c}0(0) \\
56(52.3)\end{array}$ & 3.606 & $\begin{array}{l}0.00 \\
1\end{array}$ \\
\hline $\begin{array}{l}\text { After deworming, n (\%) } \\
\text { Negative } \\
\text { Mild }\end{array}$ & $\begin{array}{c}5(4.7) \\
46(43.0)\end{array}$ & $\begin{array}{c}8(7.5) \\
48(44.9)\end{array}$ & & \\
\hline
\end{tabular}

*Wilcox on test

\section{Discussion}

Helminthiasis was still the main problem in developing country. Its impaired to nutrition, vitamin deficiency, anemia and decreased productivity, growth, and development of children, learning, and school performance. As recommended by the WHO, vitamin A and deworming tablets are distributed together by control programmes in many countries. However, there was very little known about the effects of vitamin A supplementation on Ascaris lumbricoides infections. We investigated the effects of vitamin A supplementations (mega-dose; 200,000 IU) on the Ascaris lumbricoides reinfection [9-13].

The finding of this study showed that the incidence of ascariasis was still high and might become the main problem in primary school. A cross-sectional study, Jierro et al., reported that incidence of ascariasis in two elementary schools, Belawan, North Sumatera, was 37.1\% [6] but in this study, we got $75.5 \%$ incidence of ascariasis. Another research, randomized control trial, of Al- 
Mekhlafi et al., Kuala Lumpur, Malaysia, reported that $67.8 \%$ incidence of ascariasis in elementary school [14]. Research from Pasaribu et al. in Suka village, Karo region, North Sumatra, reported that $89,7 \%$ children infected of ascariasis [5]. As our knowledge, ascariasis was still the main problem in North Sumatra and highly endemicity.

The use of $400 \mathrm{mg}$ albendazole in eradicating Ascaris lumbricoides reached 92.3\%, it meant that albendazole showed no resistance. Lubis et al. study reported that given of $400 \mathrm{mg}$ albendazole could decrease Ascaris lumbricoides infection 97.6\% approximately in primary school children $[5,7]$ also reported that prevalence of Ascaris lumbricoides infection decreased to $10.4 \%$ after giving $400 \mathrm{mg}$ albendazole [5].

Al-Mekhlafi et al. reported reinfection of Ascaris lumbricoides among children given albendazole-vitamin A and albendazole-placebo in 3 months follow up were significant ( $\mathrm{p}$-value $>0.05$ ) [14]. In this study also reported the same result with the previous study ( $p$-value $=0.478$ ) but there was intensity difference of Ascaris lumbricoides between two groups before and after treatment $(\mathrm{p}$-value $=0.001)$. However, Payne et al. reported a decreasing Ascaris lumbricoides infection after giving $400 \mathrm{mg}$ albendazole and 200,000 IU vitamin A at three months follow up [15-17]. The different results should be affected by others factor which influenced the reinfections and drug pharmacology.

The findings of this study showed that the effectiveness of before and after treatment (NNT, the number needed to treat) was 22.31. It meant that only one child was not reinfection from 22 children. From the results, we could imply that the treatment was ineffectiveness.

The unsuccessfulness of this study might be influenced by many factors, such as nutrition status, social, economic, sanitation, hygiene, etc. The weakness in our study was vitamin deficiency, malnourished, daily life behavior, any disease that destroyed intestinal mucous membrane were uninvestigated [18-20].

\section{Conclusions}

The prevalence and reinfection rates of Ascaris lumbricoides were found to be high in SD N Sikapas 384 Mandailing Natal, North Sumatra. Vitamin A supplementation showed no positive impact on Ascaris lumbricoides reinfection rates and intensities. Those could be due to the high endemicity of Ascaris lumbricoides infection in this community. Based on this study, the addition of vitamin $\mathrm{A}$ in albendazole was not recommended to cut down reinfection of Ascaris lumbricoides. 


\section{REFERENCES}

[1] D.P. Widjana, P. Sutisna, Prevalence of soil-transmitted helminth infections in the rural population of Bali, Indonesia, Southeast Asian Journal of Tropical Medicine and Public Health. 31 (2000) 454-459.

[2] P. Yap, J. Utzinger, J. Hattendorf, P. Steinmann, Influence of nutrition on infection and reinfection with soil-transmitted helminths: a systematic review, Parasites \& Vectors. 7 (2014) 229.

[3] Suriptiastuti, Infeksi soil-transmitted helminth : ascariasis, trichiuriasis dan cacing tambang, Universa Medicina. (n.d.). http://www.univmed.org/wpcontent/uploads/2012/04/Tutik.pdf (accessed August 9, 2018).

[4] J.C. Dunn, H.C. Turner, A. Tun, R.M. Anderson, Epidemiological surveys of, and research on, soil-transmitted helminths in Southeast Asia: a systematic review, Parasites \& Vectors. 9 (2016) 31.

[5] S. Pasaribu, Penentuan Frekuensi Optimal Pengobatan Massal Askariasis Dengan Albendazole Pada Anak Usia Sekolah Dasar di Desa Suka, Pendekatan Model Dinamika Populasi Cacing, PhD Thesis, 2004.

[6] S. Jiero, M. Ali, S. Pasaribu, A.P. Pasaribu, Correlation between eosinophil count and soiltransmitted helminth infection in children, Asian Pacific Journal of Tropical Disease. 5 (2015) 813-816.

[7] I.N.D. Lubis, S. Pasaribu, C.P. Lubis, Current status of the efficacy and effectiveness of albendazole and mebendazole for the treatment of Ascaris lumbricoides in North-Western Indonesia, Asian Pacific Journal of Tropical Medicine. 5 (2012) 605-609.

[8] R.J.M. Hurst, K.J. Else, Retinoic acid signalling in gastrointestinal parasite infections: lessons from mouse models, Parasite Immunology. 34 (2012) 351-359.

[9] E.C. Strunz, P.S. Suchdev, D.G. Addiss, Soil-transmitted helminthiasis and vitamin A deficiency: two problems, one policy, Trends in Parasitology. 32 (2016) 10-18.

[10] L.G. Payne, K.G. Koski, E. Ortega-Barria, M.E. Scott, Benefit of vitamin A supplementation on Ascaris reinfection is less evident in stunted children, The Journal of Nutrition. 137 (2007) 1455-1459.

[11] J.F. Kalumpiu, Y. Djuardi, T. Supali, Albendazole increases serum retinol concentration in primary schoolchildren with low serum retinol, Universa Medicina. 34 (2015) 121-128.

[12] D.M. Duriancik, D.E. Lackey, K.A. Hoag, Vitamin A as a regulator of antigen presenting cells, The Journal of Nutrition. 140 (2010) 1395-1399.

[13] B. Nikolay, S.J. Brooker, R.L. Pullan, Sensitivity of diagnostic tests for human soiltransmitted helminth infections: a meta-analysis in the absence of a true gold standard, International Journal for Parasitology. 44 (2014) 765-774.

[14] H.M. Al-Mekhlafi, T.S. Anuar, E.M. Al-Zabedi, M.T. Al-Maktari, M.A. Mahdy, A. Ahmed, A.A. Sallam, W.A. Abdullah, N. Moktar, J. Surin, Does vitamin A supplementation protect schoolchildren from acquiring soil-transmitted helminthiasis? A randomized controlled trial, Parasites \& Vectors. 7 (2014) 367.

[15] K.A. Hoag, F.E. Nashold, J. Goverman, C.E. Hayes, Retinoic acid enhances the T helper 2 cell development that is essential for robust antibody responses through its action on antigen-presenting cells, The Journal of Nutrition. 132 (2002) 3736-3739. 
[16] B. Speich, S.M. Ali, S.M. Ame, M. Albonico, J. Utzinger, J. Keiser, Quality control in the diagnosis of Trichuris trichiura and Ascaris lumbricoides using the Kato-Katz technique: experience from three randomised controlled trials, Parasites \& Vectors. 8 (2015) 82.

[17] V.L.T. Mati, H.A. Pinto, A.L. de Melo, Evaluation of Kato-Katz and spontaneous sedimentation methods for the diagnosis of platynosomiasis in Neotropical primates, Revista Brasileira de Parasitologia Veterinária. 24 (2015) 108-113.

[18] J. Bethony, S. Brooker, M. Albonico, S.M. Geiger, A. Loukas, D. Diemert, P.J. Hotez, Soil-transmitted helminth infections: ascariasis, trichuriasis, and hookworm, The Lancet. 367 (2006) 1521-1532.

[19] P.S. Suchdev, S.M. Davis, M. Bartoces, L.J. Ruth, C.M. Worrell, H. Kanyi, K. Odero, R.E. Wiegand, S.M. Njenga, J.M. Montgomery, Soil-transmitted helminth infection and nutritional status among urban slum children in Kenya, The American Journal of Tropical Medicine and Hygiene. 90 (2014) 299-305.

[20] J.E. Weatherhead, P.J. Hotez, Worm Infections in Children., Pediatrics in Review. 36 (2015) 341-52. 